FACTA UNIVERSITATIS

Series: Law and Politics Vol. 17, N² 2, 2019, pp. 159-172

https://doi.org/10.22190/FULP1902159T

Review Paper

\title{
AN OVERVIEW OF GENDER MAINSTREAMING IN UN PEACE OPERATIONS
}

\author{
UDC 327:327.56 \\ $341.123 U N(100)$
}

\section{Goran Topalović}

International and European Studies, Faculty of Political Science, University of Belgrade,

Belgrade, Republic of Serbia

Training in Peacekeeping Operations Center of Serbian Armed Forces, Belgrade, Republic of Serbia

Operations at Center for Intercultural Dialogue and Mediation - Conflux Center,

Belgrade, Republic of Serbia

\begin{abstract}
This paper provides an overview of gender mainstreaming in military components of the UN Peace Operations (POs). The main hypothesis is whether more attention is given to gender perspective and gender mainstreaming in POs that could vastly contribute to operational efficiency in the field, to better protection of human (women's) rights, to the higher level safety of the troops in the field and local population, and most importantly, whether peace could be built on solid basis and whether victimization could be avoided up to maximum possible extent. The main identified gap is a lack of appropriate training and education in this regard. Analyses of recent developments in POs, the UN Security Council Resolution 1325, gender policy in military components, and historical aspects of gender roles in Western society are considered through feminist approach to international law perspective introduced by Christin Chinkin in 1991.
\end{abstract}

Key words: Peace Operations, Gender roles, Gender mainstreaming, Military Component, UNSCR 1325

Received May $17^{\text {th }}, 2019 /$ Accepted July $9^{\text {th }}, 2019$

Corresponding author: Lieutenant Colonel Goran Topalović MA, PhD Candidate, International and European Studies, Faculty of Political Science, University of Belgrade, Belgrade, Republic of Serbia; Head of Training in Peacekeeping Operations Center of Serbian Armed Forces, and Co-founder and Director of Operations at Center for Intercultural Dialogue and Mediation - Conflux Center, Serbia; goran.topalovic@ confluxcenter.org 


\section{ROAD MAP}

The first part of this paper will provide a historical overview of gender roles in Western society in order to ensure a better understanding of actions that need to be performed today in order to fight with the root cause of gender based discrimination, particularly in the area where states are weak. The second part will elaborate on the importance of UNSCR $1325^{1}$, including the consequences that it has had in the field of UN Peace Operations (POs) ${ }^{2}$. The third part of this paper will focus on explaining why gender matters and how gender is mainstreamed in UN POs. It will be followed by negative and positive practical examples and recommendations for future integration of gender sensitive approach in all aspects of any POs. In the conclusion, the author will provide the main recommendations for future work on gender mainstreaming in the military components of different international and regional organizations and identify the major obstacles to that process today.

\section{HISTORICAL OVERVIEW}

Until just a couple of centuries ago, history of human beings was closely bonded and under a huge influence of religion, or more precisely, under the influence of religious institutions. Thus, the attitude of the Church toward women in Western Europe as well as the attitudes of enduring philosophers toward women throughout history have shaped the problems which we are still facing today. As already stated, a historical overview of relations between the Church and women in Western Europe could to some extent give answer to the question why women were excluded from the public sphere in the western civilization for centuries. The focus on only these two domains, religion and philosophy, does not mean that women were not excluded from other spheres of human interests (like literature, culture or politics), nor will it be elaborated further what situation was like in other territorial domains (Asia, Africa, etc.).

During the pre-Christianity period, the position of women and children could be best explained by invoking the genealogy of the word "family" whose origin comes from a Latin word "famulus", which refers to all house slaves, including women and children. Going further and analizing dominant religions in this teritorial domain, which more or less belonges to Abraham`s inheritance, it has to be admitted that religion contributed to increasing the visibility of women, children and poor people, at least in the religious context. Notably, in its early days, Christianity was called the religion of women, or religion of the poor. Also, one of the first prohibitions in Quran ${ }^{3}$ is that it is prohibited to kill female children. Additionally, marriage agreements were first introduced by the Church. Previously, the acceptance to marriage by women was never questioned. But, throughout history, religious institutions had excluded women from public life by neglecting Christ's words that woman and man are two in one body. This was done in the cruelest ways.

\footnotetext{
${ }^{1}$ United Nations Security Council Resolutions No. 1325 on Women, Peace and Security, 2000.

${ }^{2}$ The term "Peace Operations" is used by UN while the term "Peace Support Operations" is used by the NATO. The EU refers to it as "Military Operations". Speaking of contemporary POs and how gender is mainstreamed through all its activities, this paper will primarily explore how gender perspective is incorporated in the military component.

${ }^{3}$ Quran (eng.) - the Holy book of Islam
} 
Women were identified as "Devil's assistants" Jean Delumeau ${ }^{4}$ explains that there was a need to find someone to blame for all wars, diseases and schisms that had been happening all the time. Priests and monks were particularly good at this, which helped develop a special relationship between them and men. For example, a priest or monk was not allowed to criticize a husband in front of his wife. Jean Delumeau explains this by controlled or locked libido which was transformed to open aggressiveness. Sexually frustrated brothers projected on women what they did not want to see in themselves. But, the problem was that frustration and aggressiveness went too far. For example, women's smell was identified as early sign of internal rotting; women became the Master of death because they brought us mortal to the world and when someone dies he or she goes back to her; women's sexuality was constantly downgraded due to the adoration of Virgin Mary, etc. (Delumeau, 1978).

There are two interesting pieces of work from the Middle Ages which may serve as illustration. One of them is "De planctu ecclesiae", written by Alvaro Pelayo in 1474, printed in Ulm, and reprinted in Lion in 1517 and in Venice in 1560. This work enumerated more than 200 women's sins and vices. The second work is "Malleus maleficaruum", written by Catholic clergyman Heinrich Kramer in 1520 and reprinted more than fifteen times in the period between 1574 and 1669. This work significantly contributed to scarification of women. In medieval times, such writings were used as guidelines for "witch-hunting" and they could be blamed for death of dozen thousands of women (most frequently by incineration) throughout Western Europe and Northern America. They also included perfectly explained methods how to threat and punish women accused of witchcraft. In fact, women were accused, tried and convicted all at once. One of the methods was described as follows: if someone doubts whether a woman is a witch or not, he should tie her hands behind and put some weight, preferably stones, on her legs, and then throw her into deep water. If she does not drown, she is a witch and should be burned (Mackay, 2009). There were a lot of similar examples from the history of human society but, when talking about knowledge, it is critical to understand whose knowledge is relevant. In her work "The Man of Reason: "Male" and "Female" in Western Philosophy", Genevieve Lloyd explains the issues which all contemporary feminist epistemology is based on. She excludes the ideal of objectivity from history of philosophy and shows that the concept of rationality and reasoning in Western philosophy in the past centuries is gendered or androcentric (Lloyd, 1984).

Many great philosophers (such as Aristotle, Georg Wilhelm Friedrich Hegel, Arthur Schopenhauer, Otto Weininger, Friedrich Nietzsche, etc.) openly stated that women are less reasonable than men. They also claimed that the role of woman is complementary to the role of man since rationality is not an attribute of women. This kind of reasoning contributed to developing the idea of superior masculinity and inferior femininity. Such gender-colored philosophy from the past is becoming visible now, while objectiveness in research remains an ideal for the future. In Western Europe, it was only in the $20^{\text {th }}$ century that women started being considered as reasonable human beings, as rational as men.

By the end of the first half of the $20^{\text {th }}$ century, many declarations and conventions were made at the global level for the purpose of promoting human rights and freedoms, such as: the 1776 Unanimous Declaration of Independence of the thirteen United States of America, the 1789 French Declaration of the Rights of Man and Citizen (La Déclaration des droits de l'homme et du citoyen), the 1948 UN Universal Declaration of Human Rights, and the

\footnotetext{
${ }^{4}$ Jean Delumeau (1923-) - French historian
} 
1950 European Convention on Human Rights. Yet, it remains unclear why it was necessary to adopt dozens and dozens of new agreements, charters, manifests, declarations, directives, (etc.) which only state that the reference to "men" also implies women. This shows that international law cannot be considered as an autonomous entity, distinct from the society it regulates. On the contrary, it always depends and is under the influence of political, economical, historical, cultural, and many other contexts in which people live. In other words, a legal system tends to create and perpetuate an unequal position of women. This is why all legal documents and policies should be tested against the feminist analysis which claimed that "legal systems privilege men and if women's interests are acknowledged at all, they are marginalized" (Charlesworth, Chinkin, Wright, 1991: 615). This is the author's perspective for the purpose of this article, which attempts to identify how legal and policy system in UN Peace Operations, enhanced with institutional (military) culture, keeps resisting the gender mainstreaming despite different obligations and premises of UNSCR 1325.

The present is surrounded by the past. To paraphrase French philosopher Michel Foucault $^{5}$, thinking of the present is the only thing that does not put someone in the shoes of a prophet. Thus, in order to better understand the phenomenon of gender inequality as existing today, it is necessary to provide an overview of the period which created the present state of affairs. Yet, it could be said that half of the story is missing, as noted by Simone de Beauvoir ${ }^{6}$. Throughout history, women were excluded from the public life and their freedom of action was limited in every aspects of life. However, freedom is a precondition for public action, as Hannah Arendt $^{7}$ emphasized. Today, in the modern world, we are probably more than ever surrounded by the past.

\section{UN SECURITY COUNCIL RESOLUTION 1325}

This part of the article will focus on the contemporary role of women in the world peace and security, having in mind that all previously said has a significant impact on this issue. UN Peace Operations (POs) are among the most important activities related to peace and security that the UN and particularly the Security Council have at their disposal. Every PO is established by a UNSC resolution. The respective resolution gives mandate and legal background to each PO. Besides enacting resolutions, the UNSC acts in accordance with demands in the field and introduces other resolutions which are mandatory for every PO. One of them is UN Security Council Resolution 1325 on "Women, Peace, and Security", adopted in October $2000^{8}$. UNSCR 1325 represents a turning point in the international community in terms of women's rights, gender issues, and sexual and gender-based violence (SBV and GBV) in the conflict zones.

UNSCR 1325 needed to be adopted from various reasons. A couple of key indicators will be given in following text. The UN data of that time stated that in all conflicts that had happen after World War II (WWII) until 1998, there were 80 millions of victims (20 millions of killed and 60 millions of injured persons). As compared to WWII where the number of killed or injured soldiers and civilians was approximately the same, in the period after WWII more than $90 \%$ of victims were civilians. A comprehensive analysis

\footnotetext{
${ }^{5}$ Michel Foucault (1926 - 1984), French philosopher.

${ }^{6}$ Simone de Beauvoir (1908-1986), French philosopher.

${ }^{7}$ Hannah Arendt (1906-1975), German political theorist.

${ }^{8}$ UN Security Council Resolution 1325 on "Women, Peace, and Security", adopted on 31 October 2000, available at https://www.un.org/ruleoflaw/files/res_1325e.pdf
} 
made by the International Committee of the Red Cross (ICRC) states that the victim ratio in World War I (WWI) was approximately 20 combatants to 1 civilian. In WWII, the ratio was almost equal and, today, the ratio is 10 civilians to one soldier (ICRC, 1999: 34). ${ }^{9}$ The data show that the total number of civilian victims (children and women) exceeds the number of killed combatants. Going even further, a potential nuclear conflict would cause a ratio of 100 civilians to one soldier, while terrorism targets civilians only. In the other words, as the nature of armed conflicts has changed, the civilians have become the overwhelming majority of victims.

A detailed gender analysis of contemporary conflicts will bring even more devastating results, like the one from Liberia's conflict. According to the UN data, in both civil wars in Liberia (1989-1996 and 1999-2003), a total of 93.9\% of all female population (women and girls) were victims of GBV or SBV, while $73.9 \%$ out of the $93.9 \%$ were raped. Actually, rape became a method of warfare. There are many similar cases and data related to phenomenon of nature of contemporarily conflicts which bring similar statistics. Even when POs were established, like in Ruanda or Somalia, they failed to protect those who could not protect themselves. In addition, the 2000 UN Convention against Transnational Organized Crime and the Protocols thereto showed that the situation was the same with human trafficking, where more than $90 \%$ of victims are women and children. Obviously, this issue could not have been treated by old methods and there was a need to introduce a new approach which would address those primarily affected. UNCS Resolution 1325 was a logical consequence on the changed nature of armed conflicts.

UNSCR 1325 was adopted invoking previously adopted Resolutions 1261 and 1265 from 1999, which are related to protection of civilians in armed conflicts, and Resolutions 1296 and 1314 from 2000, which refers to problem of children in armed conflicts. The 1995 Fourth World Conference on Women and the Beijing Platform for Action adopted in September 1995 are considered to be the predecessors to the UN SCR 1325; they showed that women's organization had been working hard to raise awareness about women and children's sufferings during armed conflicts and to have these issues classified as security matter. UNSCR 1325 is mandatory for all POs to implement its provisions; it is not obligatory for member states but they are recommended and given guidelines in terms of its implementation. Some states have already developed National Action Plans (NAPs) ${ }^{10}$ in order to incorporate the resolution provisions into their legal frameworks, while some other states have hardly done anything about it. UNSCR 1325 expresses the need to incorporate the recommendations related to training of all future mission personnel. The Secretary General is expected to provide guidelines and training materials related to protection, rights and special needs of women. From the UN perspective, it may be said that everything has been done to encourage contributing states to implement this type of training into mandatory pre-deployment training, but the final word is yet up to contributing states. This kind of training has also become part of induction training in the mission area which is organized by UN, as well as part of the specific mission training. Contributing states are also invited to financially support this type of training held by different national and/or international specialized training centers.

\footnotetext{
${ }^{9}$ International Committee of the Red Cross (ICRC) Report (1999): Arms Availability and the situation of civilians in armed conclict (p.3-4), https://www.icrc.org/en/doc/assets/files/other/icrc_002_0734_arms_availability.pdf

${ }^{10}$ For more detail see: Peace Women. org (2019): National Action Plans for the Implementation of UNSCR 1325 on Women, Peace and Security; available at https://www.peacewomen.org/member-states (accessed $14^{\text {th }}$ July 2019)
} 
One of the crucial characteristics of UNSCR 1325 is that the UNSC has decided to be actively involved in these issues from the moment of adopting the resolution, which has been proven so many times. For example, numerous of resolutions dealing with similar issues were adopted afterwards, such are: Resolution 1820 (2008), Resolution 1888 (2009), Resolution 1889 (2009), Resolution 1960 (2010), Resolution 2106 (2013), Resolution 2122 (2013), etc. UNSC Resolution 1820 (2008) is related to sexual-based violence (SBV) in armed conflicts, pointing that there are more and more examples that this kind of violence is used as a tactic of warfare. This Resolution proclaims SBV as a war crime, crime against humanity, or one of the constitutive acts of genocide. Consequently, this kind of violence is now entered into the list of war crimes of the Rome Statute (article 8, paragraph 2) of the International Criminal Court, which is in charge of adjudicating such cases. Notably, this gender sensitive issue (whether organized rape during armed conflicts should be considered or treated as a war crime or as a criminal act as it used to be) was raised only after the cases of organized rape of men during civil wars in Croatia and Bosnia and Herzegovina from 1991 to 1995 . In other words, the approach to this phenomenon was androcentric again, as it has been in so many other cases. The other aforementioned resolutions were aimed at creating the international framework and mechanism for the implementation of gender perspective into international security and POs.

By enacting UNSCR 1325, the Security Council wanted to reaffirm the importance of women's inclusion in conflict prevention and conflict resolution processes. UNSCR 1325 emphasizes equal participation, not only in conflict resolution and conflict prevention but also in all processes aimed at promoting peace and security, including all decision making processes. UNSCR 1325 reminds that full implementation of International Humanitarian Law and Human Rights (IHL and HR) provisions is needed, particularly those aimed at protecting specific women, boys' and girls' rights. In addition to the four Geneva conventions from 1949, accompanied by three additional protocols (two from 1977 and third from 2005) which establish the principle of non-discrimination between men and women in terms of the basic protection during armed conflicts, there are many other documents which recognize the need for additional protection of women in armed conflicts due to their specific needs. Some of the documents which take into account women's experience and perspective are the 1993 Vienna Declaration and Programmed of Action, and the 1979 Convention on the Elimination of All Forms of Discrimination against Women (CEDAW).

UNSCR 1325 pays special attention to the need of demining. According to UN data from 2010 , in nearly 70 states there are more that 100 million unexploded different types of mines Mine fields cover approximately 200.000 square kilometers, which equals the size of Romania. In that area, women are exposed to the risk from mine fields on a daily basis. According to the same UN source, every 28 seconds someone activates a mine which kills more than 18,000 people annually. More than $80 \%$ of all victims are civilians (women and children). Also, these who suffer this kind of injuries are later exposed to discriminatory treatment, such are: public isolation, economic power loss, limited access to medical care, etc. (Landmine Action, 2003) ${ }^{11}$. UNSCR 1325 urges for providing help to these population categories.

\footnotetext{
${ }^{11}$ Landmine Action (2003). Exclosive Remnants of War: A global survey, written by John Borrie, published in June 2003 by Landmine Action, London, UK; http://www.unidir.org/files/medias/pdfs/erw-a-global-surveyeng-0-69.pdf
} 
UNSCR 1325 further stresses the importance of immediate incorporation of gender perspective into POs in two ways: first, by increasing the percentage of women in Pos and, second, by changing the mission organizational structure in order to implement its provisions. The reason why these changes are necessary will be elaborated later, but one of the main demands that is posed in front of POs is to cooperate and coordinate all activities related to incorporation of gender perspective with relevant international organization, as well as with government and non-government organization (NGO) and local women's organizations.

UNSCR 1325 also specifies the need that all statistical data which are to be produced from the time of its adoption onward should be gender sensitive. All reports which are delivered to Secretary General should have special part related to gender issues in every POs.

UNSCR 1325 calls the contributing states to ensure women representation and increase the percentage of women at every level, particularly at decision-making levels, both in the national and international institutions. The Secretary General is encouraged to implement his strategic action plan $^{12}$ in order to secure equal participation of UN employees. The Secretary General is also invited to nominate more women to be appointed for the position of UN Special Representative of the Secretary-General (SRSG). It is interesting to notice that Secretary General has appointed circa $17 \%$ of women for SRSG duties since the resolution was adopted. The Secretary General is required to ensure higher contribution of women as military observers, UN police and the personnel dealing with HR and humanitarian work within POs. UNSCR 1325 also invites parties to the conflict to undertake appropriate measures in order to ensure better protection of women and girls from any kind of SBV and GBV, and to stop the impunity of these crimes. Perpetrators should always be excluded from amnesty provisions.

Special attention was paid to the $\mathrm{DD}(\mathrm{D}) \mathrm{R}(\mathrm{R}) \mathrm{R}$ process (disarmament, demobilization, rehabilitation and reintegration), which is critical for identifying different needs of women and men, ex-soldiers and/or ex-combatants. This process is also vital for a huge number of persons who depend on ex-combatants and whose needs should also be taken into account. UNSCR 1325 also encourages women who were forced to join fighting formations (mainly to work in logistics or, in many cases, as sexual slaves) to take part in $\mathrm{DD}(\mathrm{D}) \mathrm{R}(\mathrm{R}) \mathrm{R}$ programs and to benefit from them. This category of women was previously excluded from this process, or simply forgotten, and due to cultural limitation they could not return to their former community. This issue was identified and addressed by the resolution provisions as well.

By UNSCR 1325, the Security Council invoked the application of Article 41 of the UN Charter in case of organized violation of women and girls' rights, which will be considered as a treat to international peace and security. In that case, the use of force may be allowed against the perpetrators, regardless of whether it is a state or an armed group. Action may also entail the application of other instruments, such as: sanctions, diplomatic isolation (etc.), which also represents a turning point in international relations.

At the end, it may be said that UNSCR 1325 represents an international framework and a cornerstone for more effective functioning of POs, peace negotiations and peace-building processes by the international community. In other words, it addresses many women-related issues in different peace and security contexts, as well as with the Security Sector Reform

\footnotetext{
${ }^{12}$ UN Secretary General Strategic plan for action (A/49/587), available at https://www.securitycouncilreport. org/atf/cf/\%7B65BFCF9B-6D27-4E9C-8CD3-CF6E4FF96FF9\%7D/WPS\%20A\%2049\%20587.pdf (accessed $11^{\text {th }}$ July 2019)
} 
(SSR) and political participation of women in decision-making processes. It is already common practice to say that UNSCR 1325 stands on four pillars: participation, protection, prevention (the first three pillars are known as “3-P”) and gender mainstreaming.

\section{GENDER MAINSTREAMING IN POS LED BY UN}

As it was previously stated, without understanding gender roles, we cannot understand the core values of particular societies and properly address the need of the victims. We will not analyze here why women and children are particularly vulnerable but it has to be noted that it is not because they are weak but because their gender roles limit their potential in the public sphere. Children are vulnerable because they are trustful, not because they are not educated or experienced enough. We are all aware of the importance and existence of gender roles, but some people misused them. It should be prevented by all means by gender mainstreaming.

\subsection{Why Gender matters?}

There are many gender categories and POs are at least expected to deal with men, women, boys and girls. This distinction has been made due to the previously shown nature of contemporary conflict. It is also critical to understand that gender roles are extremely environmentally and contextually dependant. Gender roles are formed for each gender category, depending on how each role is expected to be performed in terms of culture, tradition, beliefs, convictions, etc. For example, a woman in Germany and a woman in India have the same sex but perform different gender roles. Gender roles are also timedependant. For example, a French woman born in the $17^{\text {th }}$ century had different gender roles from a woman born in the $21^{\text {st }}$ century. So, gender roles are constantly changing, at a faster or slower pace, but the critical word is "change". A person has to understand that his/her culture, tradition, conviction, time, religion, beliefs, development, context (etc.) are wide-angle (landscape) lenses through which he/she sees the world around him/her. This is an easier part, but it is much more difficult to understand that those lenses are not made out of the same materials elsewhere. In order to be able to apply appropriate measures in order to achieve desired effects, one has to see the world through the victim's lenses. This could be done only if their gender perspective and their gender category representatives are included in decision-making and implementation processes by paying full attention to the environmental and contextual dependence of their gender roles. In all other cases, when gender perspective is not included, the effects of actions performed in the field will work against the victims and all those who should protect and empower them.

Thus, conflict must be seen from the victims' perspective in order to understand their current and future needs. POs must fight discrimination which existed in the respective society prior to conflict. All GBV and SBV-related offences that happened during the conflict have their origin in the past; if these issues are not addressed and treated properly after the conflict, it may serve as confirmation for impunity. Inactivity may only compound the formerly existing discrimination. Gender-based discrimination just became more visible during the armed conflict. This is why gender matters for the success of a mission as a whole. Promotion of gender equality is just the first step in this regard because there is much more to be done. 


\subsection{Gender mainstreaming}

Gender perspective is mainstreamed throughout UN led POs by structural changes embodied in establishing new units whose primarily task is to deal with implementation of provisions of UNSCR 1325 and monitoring the units related to gender issues. These units are called Gender Units and they are embedded into the organizational structure of POs. According to UNSCR 1325, the Special Representative of the Secretary-General (SRSG) in particular POs is responsible for incorporating all provisions relevant to certain POs. Gender Units are subordinated to his/her staff, or belongs to the SRSG staff. The SRSG may have his/her Gender Adviser when necessary, particularly in robust, multidimensional or hybrid missions. Gender Units are composed of subject matter experts in different fields. They are allowed to act pro-actively or upon request of any person in need of their advisory help. Gender Units supervise whether gender perspective is incorporated in the planning process and implemented in the course of performing tasks and activities. Gender Units belong to the civilian component while connection with the military and police component is achieved by appointing Gender Focal Points (GFP) in the respective military or police component. A GFP person can be appointed at different organizational levels, if the size of the component demands so. For example, in a huge military component, each sector, brigade and/or battalion will have a GFP. These persons usually deal with training; being a GFP is just an additional task (in addition to their ordinary duties), but they need to undergo appropriate gender training or have some knowledge about it at least. GFPs maintain contact with Gender Units and act in accordance with demands posed by the Gender Unit, or propose actions which seem to be necessary to perform by other actors through the Gender Unit or by the Gender Unit itself. Additionally, GFPs have an advisory role to the commanding officers and to other staff. GFPs are in charge of mandatory in-mission gender training, which is conducted in a timely manner by subordinated units. If there is a need for additional type of training, GFPs can organize and supervise it. A GFP person is also in charge of gender-specific training of staff officers of respective command, and he/she is also part of different planning teams in order to ensure that gender perspective is incorporated. GFPs receive all training material from the Gender Unit, and that material is regularly updated in accordance with after-action reports.

The implementation of gender perspective into POs is important for the protection of fundamental human rights, safety and security of troops and personal, operational efficiency, as well as for ensuring that the mission will not compound formerly existing gender discrimination (which existed in the society before the conflict occurred) in order to avoid the victimization of these who are affected and working on eliminating all kinds of gender-based discrimination. In order to ensure the implementation on gender perspective, one must hone one's senses and try to see the local population in all its complexity. According to UNSCR 1325, while dealing with the local population, all UN personnel has to recognize and differentiate at least four gender categories (women, men, boys and girls), and constantly pay attention to how each of these gender categories is affected by any actions performed by POs in the field. This is particularly important during and after a conflict, which may affect all of them in different ways. Identification of specific needs of any of these gender categories is a critical task for Pos, and it is directly linked to the mission success. 


\subsection{Education and training}

"Education is, quite simply, peace-building by another name. It is the most effective form of defence spending there is." (former UN Secretary General Kofi Annan, 2012)

Gender training for UN Troop Contributing Countries (TCC) was first mentioned in the Peoples Millennium Forum Declaration and Agenda for Action Strengthening the United Nations for the 21st Century (May 2000) ${ }^{13}$, and the concept was developed in more detailed in the Namibia Plan of Action. ${ }^{14}$ These documents were adopted because there was an identified need for more substantial protection of civilians from the consequences of armed conflicts. The first report to the SRSG in regard to gender training was delivered in 2001. This document is known as "Implementation of the recommendations of the Special Committee on Peacekeeping Operations and the Panel on United Nations Peace Operations".

The first manual for gender training was "Gender and Peacekeeping Operations: Generic Training", published by Office for Military Affairs (OMA) Department of Peacekeeping Operations (DPKO) in January 2003. In the meantime, a number of other relevant documents were published but, as it already pointed out, the TCC is responsible for the implementation of gender training into the mandatory pre-deployment training program. Education and training is the only effective tool in the process of fighting conservative attitudes shaped by stereotypes and prejudices of male-dominated military culture toward women in uniforms. The most frequent reasons why men are reluctant to accept female soldiers in their units are gender-colored or extremely subjective and androcentric. In other words, women are often judged on the grounds of men's experiences or experiences of women from other spheres, but they were never actually given an opportunity to wear uniforms and participate in missions. In fact, women's experience is the only criteria for judging whether women are able to do something or not. Unfortunately, there is still a lack of women's experience in this regard and, until it is gained, all claims are mere speculations. An additional problem is reflected in the fact that men are the ones who have to decide whether women will wear uniforms and participate in missions. The research on this issue is extensive. ${ }^{15}$ Some studies suggest that the threshold of stress tolerance in women during military tasks is at least twice lower than that in men, that women are not physically able to carry another soldier, etc. Considering different contexts and circumstances,

\footnotetext{
13 See: 'We the Peoples Millennium Forum Declaration and Agenda for Action Strengthening the United Nations for the $21^{\text {st }}$ Century, Globalization and Development: Declaration of the Civil Society Millennium Forum, New York, 26 May 2000, available at https://www.i-p-o.org/millennium_forum.htm

${ }^{14}$ See: Namibia Plan of Action on 'Mainstreaming a Gender Perspective in Multidimensional Peace Support Operations', Namibia, 31 May 2000 https://www.un.org/womenwatch/osagi/wps/windhoek_declaration.pdf; and UN SC General Assembly (14 July 2000) https://www.un.org/documents/ga/docs/55/a55138.pdf

${ }^{15}$ For more details see:

Devaney, David K. (2012). Women in Combat Arms Units, Marine Corps Gazette; June 2012; 96, 6; ProQuest Military Collection, p.62.

Bohon, D. (2011) Feminizing America's Fighting Force, The New American, www.thenewamerican.com,

Barry, B. (2013) Women in Combat, Survival: Global Politics and Strategy, http://www.tandfonline.com/ loi/tsur20,

Sabine T, Zedlacher E, and Rene H. (2014), The War against the Female Soldier? The Effects of Masculine Culture on Workplace Aggression, University of Vienna, Vienna, Austria.

Kasinof, L.(2013) Women, War, and PTSD, The Washington Monthly, Nov/Dec2013, ProQuest Military Collection.

Emerald M. Archer (2015) The Power of Gendered Stereotypes in the US Marine Corps, Department of Politics\&History, Woodbury University, Burbank, CA, USA, www.afs.sagepub.com,
} 
the results of these studies actually reinforce prejudices and stereotypes about women in uniforms. Such assumptions are not supported by empirical evidence, simply because women have not been given opportunity to gain such military experience.

Gender mainstreaming in POs seems to be an easy task but artificial resistance is something that makes it harder. It is much easier to cope with that kind of resistance at tactical level, but it is much more difficult at the operational or strategic level. Gender mainstreaming is always fought in two fronts: within the organization, and from the organization to the local population. It is easy to say but difficult to perform.

\section{CONCLUSION}

In order to use women's full potential in Pos, a lot of work is yet to be done regarding gender issues. As a matter of fact, gender issues have never been a more relevant subject matter, which creates a window of opportunity which has to be exploited. Raising awareness of women's importance for the protection of victims and civil population in general is a major task for the future. The first step would be to understand that giving gender issues serious consideration can vastly contribute to operational efficiency in the field, the protection of human rights and safety of troops in the field, conflict prevention and conflict resolution, and most importantly, peace-building and peace-keeping efforts. There are a lot of challenges in this regard, both national and international ones. Leadership in general is still quite conservative about the implementation of gender perspective. Moreover, artificial resistance based on stereotypes and prejudice is present, particularly within the military culture which is generally resistant to any new ideas. As stated by Sir Basil Henry Liddell Hart, ${ }^{16}$ "The only thing harder than getting a new idea into the military mind is to get an old one out" (Liddell-Hart, 1944).

All things considered, the conclusion may be that education on gender issues is needed at every level, while current training is at a very low level. Unfortunately, this type of training and education is still not mandatory for contributing states, and there is no universal approach to such education and training. It highly depends on environmental and contextual circumstances. There is a lot to be done in this regard yet.

After providing a comprehensive analysis of how World War I changed the nature of warfare, Gulio Douhet said in 1920: "There are no lessons to be learned from the past. We should forget about history and the future must be approached from a new angle" (Ferrari, 1998: 120). The Great War was the turning point, but we may only hope that the turning point for future conflicts will not be so obvious. Actually, the turning point might have already occurred but we are still unaware of it. Having in mind the statistical analysis presented in the second part of this paper, this might be the case and, if so, we might have the fourth generation of warfare already in place. For the time being, all we know about this issue is that no one actually knows what the fourth generation of warfare would look like. It should be noted though that targets have changed, which is a critical characteristic of the WWI developments as compared to all previous wars, and this is what Gulio Douhet referred to. In this case, there is a need for a rational long-term approach to strategic decision-making processes.

\footnotetext{
${ }^{16}$ Sir Basil Henry Liddell Hart (1895 -1970), British Army officer, military historian and military theorist.
} 
Politics, which deal with short-term popularity, cannot cope up with these issues. In other words, we first have to focus on the targeted victims. Unfortunately, at the very beginning of implementing this long-term strategy, the UN and the entire international community were faced with cases of sexual harassment and abuse of the local population (in the Central African Republic, the Democratic Republic of Congo, etc) by members of the UN forces. As a result of these events, since July 2016, the UN officials have been requesting an official confirmation from all contributing states that a deployable unit has undergone appropriate pre-deployment training related to GBV and SBV. In the UN General Assembly session on $17^{\text {th }}$ September 2015, the Secretary General stated that he would not hesitate to repatriate the whole contingent if a single member of any contingent committed this type of violence toward the local population. This may show us future steps and trends in the field of implementation of gender perspectives into all plans, actions and tasks in POs.

At the end, it has to be noted that gender roles are not yet as important to the civilized world as they are important to those who are against all that we stand for. In April 2010, we all witnessed the words of Abdul Hadi Arghandiwal, leader of Hezb-i-Islami political party in Afghanistan, who stated that women would have to sacrifice their interests for the sake of having peace with Taliban, which is extremely necessary since coalition forces are about to be withdrawn. ${ }^{17}$ This statement is probably the best illustration about the relevance and importance of gender issues. For this reason, it is critical to raise awareness of gender roles and gender perspective and ensure the highest possible level of gender equality in the UN POs context.

'The UN was not created to take humanity to heaven but to save it from hell.' (Dag Hammarskjold, former UN Secretary General)

\section{REFERENCES}

After Action Report (2012), Teaching Gender to the Military - In the Classroom and through Advanced Distributed Learning, NATO School, Oberammergau

Annan, K. (2005), Gender and Peacekeeping Operations, United Nations Department of Peacekeeping Operations and Department for Public Information Peace and Security Section, available at: http://www.un.org/en/peacekeeping/publications/gender_brochure.pdf

Charlesworth, H., Chinkin Ch., Wright Sh. (1991), Feminist Approaches to International Law, The American Journal of International Law, Vol. 85, No. 4 (Oct. 1991), pp 613-645

Declaration of the Millenium Forum (2000): 'We the Peoples Millennium Forum Declaration and Agenda for Action Strengthening the United Nations for the $21^{\text {st }}$ Century, Globalization and Development: Declaration of the Civil Society Millennium Forum, New York, 26 May 2000, available at https://www.i-po.org/millennium_forum.htm

Delumeau, Jean (1978). Страх на западу (од XIV до XVIII века) - Опседнути град, Књижевна заједница Новог Сада, Нови Сад

Ferrari, D. (1998), The Command of the Air, Air Force History and Museums Program, Washington D.C.

Human Rights Watch (2010): The "Ten-Dollar Talib" and Women's Rights Afghan Women and the Risks of Reintegration and Reconciliation (p. 6), retrieved 17 January 2015 from https://www.hrw.org/sites/default/ files/reports/afghanistan0710webwcover.pdf

International Committee of the Red Cross (ICRC) Report (1999): Arms availability and the situation of civilians in armed conclict, a study presented by the ICRC (p.3-4), available at https://www.icrc.org/en/doc/ assets/files/other/icrc_002_0734_arms_availability.pdf

\footnotetext{
${ }^{17}$ Human Rights Watch (2010): The "Ten-Dollar Talib" and Women's Rights Afghan Women and the Risks of Reintegration and Reconciliation (p. 6), retrieved 17 January 2015 from https:/www.hrw.org/sites/default/ files/reports/afghanistan0710webwcover.pdf
} 
John, A. (2002), Learning to Eat Soup With a Knife-Counterinsurgency Lessons From Malaya and Vietnam, Greenwood Publishing Group, USA

Landmine Action (2003). Exclosive Remnants of War: A global survey, written by John Borrie, Published in June 2003 by Landmine Action, London, UK; available at http://www.unidir.org/files/medias/pdfs/erw-aglobal-survey-eng-0-69.pdf (accessed on $14^{\text {th }}$ July 2019)

Lloyd, Genevieve (1984). The Man of Reason: "Male" and "Female" in Western Philosophy, Methuen Publishing Ltd, London, UK

Mackay, Christopher S. (2009). The Hammer of Witches, A Complete Translation of the Malleus Maleficarum, Cambridge University Press, available at https://the- eye.eu/public/WorldTracker.org/College\%20Books/ Cambridge\%20University\%20Press/0521747872.Cambridge.University.Press.The.Hammer.of.Witches.A. Complete.Translation.of.the.Malleus.Maleficarum.May.2009.pdf

Peace Women (2019): National Action Plans for the Implementation of UNSCR 1325 on Women, Peace and Security; available at https://www.peacewomen.org/member-states (accessed $14^{\text {th }}$ July 2019

United Nations (2000), Report of the Panel on UN Peace Operations, available at: http://www.un.org/peace/ reports/peace_operations/

United Nations (2015), Implementing Guidelines for Military Components of United Nations Peacekeeping Missions, DPKO, New York

Uited Nations General Assembly (1979), Convention on the Elimination of All Forms of Discrimination against Women (CEDAW), (A/34/180)

UN Convention against Transnational Organized Crime and the Protocols thereto, (Palermo Protocol, adopted by General Assembly Resolution 55/25 of 15 November 2000, opened for signature at a High-level Political Conference convened in Palermo, Italy, on 12-15 December 2000, and entered into force on 29 September 2003, available at http://www.unodc.org/unodc/treaties/CTOC/

UN Department of Peacekeeping Operations Best Practice Unit (2004), Gender Resource Package for Peacekeeping Operations, available at http://www.peacekeepingbestpractices.unlb.org/pbps/library/ GRP\%20Full\%20Version.pdf

UN Department of Peacekeeping Operations Force Generation Service (2008), Generic Guidelines for Troop Contributing Countries Deploying Military Units to the United Nations Peacekeeping Missions -TCC Guidelines, available at https://cc.unlb.org/COE\%20Documents/Generic\%20Guidelines\%.pdf

UN Department of Peacekeeping Operations (2010), Guidelines for Integrating a Gender Perspective into the work of the United Nations military in peacekeeping operations, available at http://www.peacewomen.org/ assets/image/Resources/pk_integratinggenderperspectiveunmilitarypeacekeeping_undpko_march2010.pdf

UN Department of Peacekeeping Operations Department of Field Support (2010), Gender Equality in Peacekeeping Operations, available at: http://www.un.org/en/peacekeeping/documents/gender_directive_ 2010.pdf

UN Department of Peacekeeping Operations Progress Report (2013), Gender Mainstreaming in Peacekeeping Operations, available at http://www.peacekeepingbestpractices.unlb.org/pbps/Library/Gender\%20 Mainstreaming\%20Progress\%20report.pdf

UN Peacekeeping PDT Standards (2009), Core Pre-Deployment Training Materials, available at: http://peacekeepingresourcehub.unlb.org/PBPS/Pages/Public/library.aspx?ot=2\&scat=393\&menukey=_4_5_2

UN Secretary General Strategic plan for action (A/49/587), available at: https://www.securitycouncilreport. org/atf/cf/\%7B65BFCF9B-6D27-4E9C-8CD3-CF6E4FF96FF9\%7D/WPS\%20A\%2049\%20587.pdf (accessed on 11 July 2019)

UN Security Council (2000): Namibia Plan of Action on 'Mainstreaming a Gender Perspective in Multidimensional Peace Support Operations', Windhoek, Namibia, 31 May 2000, available at https://www.un.org/womenwatch/osagi/wps/windhoek_declaration.pdf; UN SC General Assembly (14 July 2000), available at https://www.un.org/documents/ga/docs/55/a55138.pdf (accessed on 11 July 2019)

UN Security Council (2015): Report of the Advisory Group of Experts on the Review of the Peacebuilding Architecture (p.3-6), UN SC General Assembly 30 June 2015, available at https://www.peacewomen.org/ sites/default/files/N1520294.pdf, (accessed on 11 July 2019)

UN Security Council (2015): Report of the High-level Independent Panel on Peace Operations, A/70/95S/2015/446, (pp. 7 onwards), available at https://www.securitycouncilreport.org/atf/cf/\%7B65BFCF9B6D27-4E9C-8CD3-CF6E4FF96FF9\%7D/s_2015_446.pdf

UN Security Council Resolution 1325 on "Women, Peace, and Security", adopted on 31 October 2000, available at https://www.un.org/ruleoflaw/files/res_1325e.pdf

UN Security Council Resolutions: 1325 (2000), 1820 (2008), 1888 and 1889 (2009), 1960 (2010), 2106 and 2122 (2013) on Women, peace and security, available at http://www.un.org/en/sc/documents/resolutions/ 


\section{PREGLED PROCESA UVOĐENJA RODNE PERSPEKTIVE U MIROVNE OPERACIJE UN}

Rad daje pregled procesa uvodjenja rodne perspektive u mirovne operacije UN. Osnovna hipoteza je da ukoliko više pažnje posvetimo uvođenju rodne perspective u mirovne operacije, to će značajno doprineti podizanju nivoa operativne efikasnosti na terenu, boljoj zaštiti ljudskih prava (prava žena), vecoj bezbednosti snaga na terenu i lokalnog stanovnistva, I što je najažnije, izgradnja mira će biti na zdravim osnovama i znacajno ce se smanjiti broj zrtava. Trenutno glavni identifikovani problem je nedostatak adekvatne obuke i obrazovanja o rodnim ulogama. Analiza poslednjih trendova na polju mirovnih operacija, odredbi Rezolucije SB UN 1325, analiza normativnih I doktrinarnih dokumenata vojnih komponenti u mirovnim misijama, ali $i$ analiza istorijskih aspekata rodnih uloga u zapadnom društvu, vrsena je sa stanovišta feminističkog pristupa međunarodnom pravu koje je 1991. godine predstavila Kristin Šnkin.

Ključne reči: Mirovne operacije, rodne uloge, uvođenje rodne perspektive, vojna komponenta, Rezolucija SB UN 1325 